\title{
FROM LIP-SERVICE TO SERVICE DELIVERY IN LOCAL ECONOMIC DEVELOPMENT: GUIDELINES TO SET UP AN AGENCY FOR ACTION
}

\author{
Marius Venter \\ University of Johannesburg \\ mventer@uj.ac.za
}

Received: June 2013

Accepted: April 2014

\begin{abstract}
The Constitution of South Africa imposes a burden on municipalities to engage in local economic development. Municipal local economic development practitioners are often in doubt regarding the various mechanisms available to them to implement local economic development. This article provides insight into the processes and issues surrounding the use of an external mechanism (a private company owned by the municipality) as a local economic development agency. The lessons learnt from the Overstrand Local Economic Development Agency are compared with findings of an international study of the Organisation for Economic Co-operation and Development on 16 local economic development agencies. The article provides guidelines to local economic development practitioners to follow before, during and after the establishment of a local economic development agency.
\end{abstract}

Keywords

Key success factors, local economic development agency, local economic development, municipality, municipal entity

Dr M Venter is the Director of the Centre for Local Economic Development, University of Johannesburg, South Africa. 


\section{INTRODUCTION}

It is generally believed that municipalities are the foot-soldiers of local economic development (LED). However, this seems to be a myth, as municipalities in South Africa have not yet fulfilled this mandate and have been struggling for several years to implement LED initiatives (Davids, 2007:3). Communities have become frustrated about the lack of LED and service delivery protests form part of our daily lives (Davids, 2012). It is evident that municipalities fail in LED partly because of a lack of expertise and partly due to the lack of a suitable organisational arrangement to promote and undertake LED in a municipal area (Rabie, 2011:6).

The Constitution of South Africa (Act 108 of 1996) specifies in sections 152 and 153 that municipalities must be structured in such a way that one of their objectives is to promote social and economic development (Rabie, 2011:5). Calitz refers to the restructuring of the public sector that took place after 1994 to introduce the development function of government (Black, Calitz \& Steenekamp, 2005:5). The White Paper on Local Government (1998) introduced the concept of LED as part of the term 'developmental local government', defining it as: "Local government committed to working with citizens and groups within the community to find sustainable ways to meet their social, economic and material needs, and improve the quality of their lives" (Patterson, 2008:7). According to the Department of Co-operative Governance and Traditional Affairs (COGTA, 2012:4) LED can make a unique contribution to national development through the effective implementation of government's economic policy at the local level, and the importance of $L E D$ is characterised by the fact that it is at the local level where all economic activity takes place and jobs are created.

There are various definitions of $L E D$, but for the purpose of this article the definition of Swinburn, Goga and Murphy (2006:1) was refined:

\footnotetext{
$L E D$ occurs when a community consciously decides to improve the economy of the area where they live, by getting all stakeholders such as the public, private and nongovernmental sector in that specific area to work together using their local assets in a manner that it creates decent jobs which will improve local living conditions ensuring a sustainable economic future.
}

South African municipal legislation (the Municipal Structures Act 117 of 1998 and the Municipal Structures Amendment Act No. 44 of 2003) gives municipalities the option to investigate the viability of setting up an external mechanism to implement LED. The external mechanism can be an LED agency. The concept of an economic development agency is described by the International Labour Organisation (ILO, 2003:19) as "functional structures that will help establish an identity and visibility for the local development initiative and act as a vehicle for communication between partners and interest groups. This structure should be tasked with drawing up a long-term overall strategic plan and help access finance for the implementation of projects. The structure should have stability and permanence, since few tangible results are achieved in less than five years and fundamental transformation requires at least ten years. It is also helpful if the structure has a degree of autonomy from political pressures so that it may develop a long-term strategy rather than be forced to respond to short term priorities." In her Country Report on LED in South Africa, (Patterson, 2008:28) states that an LED agency is "an approach for generating jobs in local communities using local knowledge and mechanisms. It involves strategic planning and research, using available tools and resources, and building partnerships between different spheres of government, the private sector and the not-for-profit 
sector." The Organisation for Economic Co-operation and Development (0ECD/Mountford, 2009) conducted research on 16 international development agencies to establish best practices for setting up and managing LED agencies. They found many different kinds of development corporations/agencies and that different names are used in different places, for instance: Development Agency, Local Development Agency, Regional Development Agency, Economic Development Agency, Economic Development Corporation, Development Authority, City Development Agency, Local Development Corporation or City Development Corporation. The different names did not suggest distinctive activities; they were often inter-changeable, and agencies with the same names frequently did very different things and had different legal structures. Furthermore, linguistic preferences determined the names used (0ECD/Mountford, 2009:12).

As recently as 2011 a consortium of universities under the guidance of the Centre for Local Economic Development (CENLED) started to develop training material that will be used as a professional development programme for LED practitioners to address the LED skills shortage. The aim of this programme is to assist LED practitioners with the relevant LED theory and applicable South African case studies. The objective of this article is to contribute a case study on an LED agency that can be used by practitioners as part of their professional development. In this article the author, the former chief executive officer of the Overstrand LED agency (OLEDA), reflects on his experiences and lessons learnt regarding setting up and managing a municipal $L E D$ agency. Guidelines to assist current and aspiring municipal LED practitioners are formulated by comparing the findings of the $0 \varepsilon C D /$ Mountford study with his experiences.

OLEDA was an LED agency set up by the Overstrand municipality to undertake LED projects. OLEDA's vision was "that the Overstrand municipal area will be developed as the most sustainable and responsible investment and tourism destination in the Western Cape", while its mission was: "To improve the quality of life of the citizens of the Overstrand municipal area by promoting innovative solutions that challenge mainstream thinking on economic, environmental and social developmental issues." (OLEDA 2008:9). In South Africa OLEDA was the first and only $L E D$ agency registered as a private company, wholly owned by the Overstrand municipally as a municipal entity to undertake LED.

This article commences with an overview of the background to the OECD. The overview is followed by an outline of the four different phases to be considered by the LED practitioner before, during and after setting up an LED agency. Throughout the discussion on the four phases, the application to the OLEDA context is highlighted and referenced to OECD/Mountford to contribute towards compiling guidelines for setting up and managing LED agencies. This discussion could provide insights to assist current and aspiring municipal LED practitioners who are considering setting up and managing an LED agency. The article closes by reporting on the challenges, benefits and pitfalls of an LED agency.

\section{CONTEXT OF LOCAL \&CONOMIC DEVELOPMENT AGENCIES}

The 0\&CD was established in 1947. The mission of the OECD is to promote policies that will improve the economic and social well-being of people around the world. One of the aims of the $0 E C D$ is to do research on economic development topics globally to assist their 34 member countries, among others, Australia, Brazil, China and Russia. The 0ECD/Mountford (2009:2) found that internationally, municipalities have been searching for years to find a suitable mechanism to do LED. According to the 0ECD/Mountford (2009:3) different waves of setting up 
LED agencies were experienced during the 1950s and 1960s. In Europe, several LED agencies were set up at municipal level and in some cases at regional level. North America followed in the 1960 s and 1970s and in the 1980s and 1990s many LED agencies were set up in parts of East Asia. From the mid-1990s many developing countries - including South Africa - started setting up LED agencies.

The research of the 0ECD/Mountford (2009:16) indicated that there is no fixed time when an LED agency should be set up. In order to make sure that there is commitment to setting up an LED agency a municipality should do its homework on what it takes. Setting up an LED agency is a complex process that can take months or even years. In the case of OLEDA the Overstrand municipality took a resolution to investigate the establishment of an LED agency in 2003, but it took five years before 0LEDA was established. The 0ECD/Mountford (2009:16) highlighted four distinct phases of the establishment of an LED agency: promoting the idea; establishing the agency; starting the activity; and consolidation. LED practitioners must note that consultation, planning, and communication form an integral part of every phase of establishing an LED agency.

\subsection{Phase one: Promoting the idea}

During this phase it is important to engage all stakeholders to gain their support for the LED agency. The primary observation of the 0ECD/Mountford (2009:19) was that it is important to engage with stakeholders in your municipal area before, during and after setting the agency up. The 0ECD/Mountford (2009:19) found that even well-managed and well-resourced LED agencies would not be effective if they operated without consulting stakeholders. The following stakeholders play an important role: members; politicians, especially the mayor; the municipal council; regional, provincial and municipal departments; the community; the private sector; the media and international partners (OECD/ Mountford, 2009:19).

The OLEDA experience confirmed this finding of the 0ECD/Mountford. The Overstrand municipality took a decision in principle to support the concept of an LED agency in 2003, but it took them five years to fulfil all the municipal legal requirements before establishing OLEDA. In OLEDA's case two additional phases were identified, namely to do a viability study and to ensure external financial support. The OECD/Mountford (2009) did not specifically report on legislative issues. The author is however of the opinion that it is important for LED practitioners in South Africa to take note of the legislation, the prescribed processes and the criteria that must be met before a municipality can decide to establish an LED agency. The establishment of an LED agency forms part of phase one. In phase one only those pieces of legislation applicable to determine the viability of the LED agency concept are discussed. The following guidelines, legislation and policies need to be noted when a municipality is considering the concept of an LED agency (URBAN - ECON Development Economists, 2009:13):

- The South African Constitution (1996)

- The Municipal Systems Act (No. 32 of 2000)

- The Municipal Systems Amendment Act (No. 44 of 2003)

- The Municipal Systems Amendment Act (No. 7 of 2011)

- The Municipal Structures Act (No. 117 of 1998)

- The Municipal Structures Amendment Act (No. 1 of 2003) 
- The Municipal Finance Management Act (No. 56 of 2003)

- National Treasury regulations No. 308 and 309 (Gazette 27431 of 2005)

- The draft National LED Framework 2012-2017 (COGTA, 2012)

- 'Policy Guidelines for Implementing Local Economic Development in South Africa'. Department of Local Government (DPLG, 2005)

- 'Stimulating and developing sustainable local economies', Department of Local Government (DPLG, 2006)

- 'A Councillor's Guide to Local Economic Development (LED) in South Africa; The Why? What? Who? and How? of LED'. Prepared by SA LED Network for the South African Local Government Association (SALGA, 2011)

- 'Key issues in LED in South Africa and a potential role for SALGA'. Prepared for the Department of Cooperative Governance and Traditional Affairs (COGTA), (SALGA, 2010)

There are a few institutional mechanisms that are available to municipalities in South Africa to expand on their service delivery mandate in respect of LED. Section 76 of the Municipal Systems Act (Act 32 of 2000) introduces these mechanisms. The first option that municipalities have is to deliver LED with an internal mechanism. Internal mechanisms include the following: a department or other administrative unit within a municipality's administration; any business unit devised by the municipality provided it operates within the municipality's administration and is under the control of the municipality with proper operational systems and performance criteria determined by the municipal council; or the service can be delivered by any other component of the municipality's administration. The second service delivery option available to municipalities is an external mechanism, for example an LED agency similar to OLEDA. This mechanism comes into operation when the municipality enters into a service delivery agreement with one of the following types of entities: a municipal entity; another municipality; an organ of state; a community-based organisation or non-governmental organisation; or any other institution. In terms of section 77 of the Municipal Systems Act (Act 32 of 2000) municipalities are required to review and decide on an appropriate service delivery mechanism (internal or external) when they are:

- preparing and/or reviewing their integrated development plans (IDPs);

- considering providing a new service;

- improving, upgrading or extending existing municipal services;

- carrying out a performance evaluation of the existing delivery mechanisms (in accordance with Chapter 6 of the Municipal Systems Act, (Act 32 of 2000);

- restructuring or reorganising functions;

- contemplating providing a municipal service through an external mechanism;

- required to do it (in terms of section 139 of the Constitution, 1996);

- anticipating that a service delivery agreement is expiring or going to be terminated within the next 12 months; or

- if the municipality is requested to do so by the local community (in terms of chapter 4 of the Municipal Systems Act, (Act 32 of 2000). 
Section 78 of the Municipal Systems Act (Act 32 of 2000) describes the criteria that a municipality must consider in deciding on the most suitable mechanism to provide the service. The following criteria and protocol must be followed:

- The direct and indirect cost and benefits associated with the project if the service is to be delivered by an internal mechanism;

- The municipality's current and potential future capacity to provide the skills, resources and relevant expertise that are needed to ensure for effective service delivery, if an internal mechanism will be implemented;

- The extent to which the re-organisation of its administration and the development of the human resource capacity within that administration as provided for in Sections 51 and 68 respectively could be utilised to provide a service through an internal mechanism mentioned in Section 76(a);

- The likely impact on development, job creation and employment patterns within the municipality;

- The views of organised labour and municipalities; and

- Any developing trends in the sustainable provision of municipal services generally.

In the case where municipalities choose to investigate the use of an external mechanism, a legislative process has to be followed. Firstly, notice must be given to the local community of the intention of the municipality to explore the provision of the service through an external mechanism. Secondly, the different service delivery options must be assessed by the municipality in terms of section 76(b) of the (Municipal Systems Amendment Act, 2003), taking into account the direct and indirect cost and benefits associated with the project. These include the expected effect of any service delivery mechanism on the environment and on human health, well-being and security; the capacity and potential future capacity of the prospective service provider to deliver the skills, resources and relevant expertise needed to ensure effective service delivery; the likely impact on development and employment patterns within the municipality; the views of the local community, as well as those of organised labour. Once the external LED service delivery mechanisms have been evaluated and the municipality is of the opinion that it can make an informed decision, a report is submitted to the council of the municipality. The full municipal council then debates the recommendations and takes a resolution whether or not an external mechanism will be used to do LED. If the municipality resolves to use an external mechanism there are legislative components which have to be complied with pertaining to the appointment of a service provider other than the municipality. It is advisable for the municipality to appoint a dedicated 'champion' to implement the resolution of the council.

If the external mechanism is an LED agency similar to OLEDA, the next important step is to decide on the financial model to finance the LED agency. The 0ECD/Mountford (2009:17) identified five practices for financing LED agencies:

Model 1: The LED agency is wholly owned and funded by the municipality and its budget is controlled in detail through municipal accounting processes.

Model 2: The LED agency is wholly funded and owned by the municipality but has the freedom to use the proceeds of capital receipts, trading income, fees, and levies (for example) to generate a 'sustainability' fund which is subject to municipal accounting rules. These funds may be used to achieve agency objectives. 
Model 3: The LED agency is funded from a range of public and private sector sources and there are clear rules and processes for setting the financial strategy and for the reapportioning of income.

Model 4: The LED agency is funded by the private sector and operates as a not for profit business with extensive control over its internal financial strategy.

Model 5: The LED agency has created its own 'subsidiary' or 'intermediary' for engaging in more complex financial transactions and is separately governed and accounted for within approved rules.

The 0ECD/Mountford (2009:17) came to the conclusion that depending on the regulatory frameworks, LED agencies should have the freedom to develop their own model. Once an LED agency is up and running, consideration must be given to finding ways of generating additional income. According to the $0 E C D / M o u n t f o r d ~(2009: 17)$ there are activities that LED agencies may investigate as sources to generate additional income. These include participating in the capitalisation of small businesses; consultancy services; real estate and property management and development; providing training; organising seminars; attracting sponsorships; trade missions; services for foreign investors; management of incubators and industrial parks; and the sale of publications.

OLEDA's financial model corresponded with Model 2 of the OECD finding. OLEDA was regulated by the Municipal Management Finance Act, (Act No. 56 of 2003) (MFMA). The budget was monitored and annually appraised against the agreed performance objectives and indicators and depended on transfers from the Industrial Development Corporation (IDC) and the Overstrand municipality. In South Africa, the Agency Development Support (ADS) department of the IDC is responsible for providing external funding for municipal $L E D$ agencies. A municipality has to apply to the IDC for funding and then prepare and submit a business plan annually. The funding is approved for five years, totalling approximately R25 million, but a business plan must be submitted annually. This is a conditional grant and therefore if the milestones proposed in the business plan are reached, the agency does not have to pay anything back to the IDC.

OLEDA also investigated additional ways by which to raise the income within certain limits. According to legislation a municipal entity in South Africa (as was the case with OLEDA) must restrict its activities to the purpose for which it is used by its parent municipality. An LED agency has no competence to undertake any activity which falls outside the powers and functions of the parent municipality (Fourie \& Opperman, 2011:78). The next step would be to prepare a business plan to secure funding. After the parent municipality has approved the business plan, the champion must ensure that suitable office space, telephones and office furniture and equipment are procured or reserved for the LED agency before going into phase two. These expenses will normally be borne by the parent municipality as its contribution to set-up costs.

\subsection{Phase two: Establishing the led agency}

Phase two consists of seven steps as described below.

Step one: Determine the legal structure of the LED agency.

After the municipality has taken a resolution to establish an LED agency, a decision must be made on the type of legal entity to be established; the appointment of a board; the competencies required to do the work; and the objectives of the LED agency. Municipalities internationally give preference to appropriately regulated structures (defined as companies, 
agencies, or corporations), rather than managing them from within a municipality (a municipal department or service directorate). The reason for this is that an LED agency outside the municipality is seen as a corporate structure which is more professional (0ECD/Mountford, 2009:2). OLEDA was registered as a private company with the Registrar of Companies under the Companies Act, 1973 and established in terms of the provisions of the Municipal Systems Act (Act 32 of 2000) and the Municipal Finance Management Act (Act 56 of 2003).

Step two: Determine the role of the LED agency.

The LED agencies analysed by the 0ECD (OECD/Mountford, 2009:9) showed four major organising roles. These roles must be considered before the LED agency's objectives are determined. Firstly, an economic role is considered where development is facilitated by the LED agency using municipal-owned assets, infrastructure, land or property. Secondly, a leadership role is a possibility which entails interacting with all stakeholders in the area to plan an economic development vision and plan for the area. Thirdly, the LED agency might decide to have an advocacy and co-ordination role where dialogue is facilitated to overcome barriers to economic development. Finally, the LED agency might have an implementation role.

In the case of OLEDA the municipality decided that the best organisational arrangement was an $L E D$ agency managed outside the municipality, although it kept its in-house LED unit. The role of OLEDA was to act as the implementation arm of the Overstrand municipality in respect of certain $L \varepsilon D$ projects.

\section{Step three: Appoint a board of directors}

OLEDA was governed by a board of non-executive directors with a non-executive chairman and administered by a Chief Executive Officer (CEO). The board of directors consisted of seven board members representing the different areas in the Overstrand.

Step four: Determine the mandate and type of the LED agency.

The 0ECD study (0ECD/Mountford, 2009:13) categorised LED agencies in the following mandate categories: crisis response; initiating local development; business interface; special zone or district; positioning and promoting; aggregator; flexibility; leverage; transparency; and risk and cost savings. These categories are self-explanatory.

As was the case with OLEDA, the OECD study (0ECD/Mountford, 2009:14) concluded that a few $L E D$ agencies would be operating under all of these mandates simultaneously, but that many would have more than one to pursue. OLEDA had to pursue the 'initiating local development'; the 'business interface'; the 'aggregator'; the 'positioning and promotion'; the 'flexibility'; and the 'transparency' mandate.

The 0ECD study (0ECD/Mountford, 2009:7) indicated that LED agencies might also conform to certain types, for example the 'local', focusing on a specific geographical area; or 'regional', where two or more municipalities partner to set up an LED agency or in certain instances an LED agency might be operating within a municipality. In this case, the unit is 'branded' to do the LED as an agency and the function and finances are ring-fenced, giving the internal LED agency greater operational freedom.

OLEDA was specifically set up as an 'external, local' agency to focus on projects on specific pockets of land in the marginalised areas of the towns Hermanus, Gansbaai, Stanford, Hangklip/Kleinmond, Pearly Beach and the rural areas Buffeljags and Baardskeerdersbos. In the 
case of OLEDA the prospect of establishing a 'regional' LED agency was slim, because different political parties ruled the different municipalities and their vision in respect of LED differed.

Step five: Determine the objectives of the $L E D$ agency.

Internationally, municipalities have created LED agencies to pursue different objectives (OECD/Mountford, 2009:2). Some of the objectives are to market the municipality to attract investment, to redevelop damaged or derelict sites or to stimulate the economy (such as a defence base, a major factory, or a port) (0ECD/Mountford, 2009:2).

In terms of the service delivery agreement with the Overstrand municipality, the following objectives of OLEDA (OLEDA, 2008:3) were articulated:

- Act as the operational arm of the municipality for purposes of implementing economic, social and environmental policies and projects within the Overstrand Municipal Area;

- Promote and develop the economic potential of the Overstrand Municipal Area;

- Develop the innovation and entrepreneurial potential and activity which support and drive economic growth within the area of jurisdiction of the municipality;

- Co-ordinate the identification and implementation of a long- and short-term development programme through identified projects in agreed precincts, including its spatial, economic, social and environmental dimensions, its regulatory, budgetary, financial and legal implications and its social and economic consequences;

- Conduct a regular communications programme with all stakeholders;

- Leverage public support and private resources for development around opportunities which offer economic and development potential;

- Provide a 'one-stop' contact point for local and foreign entrepreneurs intending to invest and/or partake in the development of the Overstrand Municipal Area;

- Acquire, own and manage land and buildings, and/or rights to land and buildings necessary to enable it to achieve its stated aims and objectives;

- Negotiate, enter into and administer contracts in furtherance of its objectives;

- Commission, undertake or manage and monitor any study that may be necessary to further the objectives of the Agency; and to

- Collect income, raise, receive and hold funds, or receive guarantees, from any lawful source, for the purposes of the Agency and to manage, administer and disburse those fund in pursuance of the objectives of the Agency and for administrative purposes.

Step 6: Determine the projects of the $L E D$ agency and re-draft the business plan.

The lessons learnt from OLEDA are that it is advisable to start with one or two projects. Initially, the LED agency has to develop and implement systems, policies and procedures. The implication is that in the first year, projects can only be planned and not executed. It is important for stakeholders (including the parent municipality) to know that execution will start only in year three, and that expectations and targets in respect of what the LED agency can achieve should be realistic. The project cycle is also influenced by the public participation processes, environmental impact assessments, viability studies, political promises and a lack of resources. 
Step 7: Determine the job competencies required to inform the organogram.

The OECD report (OECD/MOUNTFORD, 2009:11) established a range of competencies that the LED agencies expected from the LED practitioners that would be working in the LED agency. OLEDA had similar requirements in the CEO's job description.

The various competencies indicated in TABLE 1 are examples to be included in the job descriptions of the LED practitioners.

\section{TABLE 1: $\quad 0 E C D / O L E D A$ competencies and job descriptions relating to LED practitioners}

\begin{tabular}{|c|c|}
\hline Competencies & Job descriptions \\
\hline Strategic competencies & $\begin{array}{l}\text { - } \text { - Costering coalitions for growth initiatives } \\
\text { - Co-ordination of regional, national and international investors } \\
\text { or donors } \\
\text { - Monitoring the municipal economy } \\
\text { - } \quad \text { Strategic planning for economic and local development } \\
\text { - Infrastructure and investment advocacy }\end{array}$ \\
\hline $\begin{array}{l}\text { Asset and investment } \\
\text { competencies }\end{array}$ & $\begin{array}{l}\text { - Land and property redevelopment and management } \\
\text { - Fund management and direct lending/investment in firms } \\
\text { and/or investment projects } \\
\text { - } \quad \text { Other forms of financial intermediation and income or resource } \\
\text { generation } \\
\text { - The management of grant aid for businesses and other } \\
\text { organisations }\end{array}$ \\
\hline $\begin{array}{l}\text { Innovation, enterprise, skills, } \\
\text { and employment } \\
\text { competencies }\end{array}$ & $\begin{array}{l}\text { - Promoting technology, creativity, and innovation } \\
\text { - } \quad \text { Forkforce development and skills development } \\
\text { (SMEs) } \\
\text { - Employment creation and job brokerage }\end{array}$ \\
\hline Promotional competencies & $\begin{array}{l}\text { - Marketing and facilitation of foreign investment promotion of } \\
\text { other forms of external investment (e.g. tourism, events, } \\
\text { trade, sports) } \\
\text { - Project management and designing of major projects }\end{array}$ \\
\hline $\begin{array}{l}\text { Capacity-building } \\
\text { competencies }\end{array}$ & $\begin{array}{l}\text { - Sector and cluster development programmes } \\
\text { - Capacity-building and technical assistance for other local } \\
\text { organisations } \\
\text { - Identification of good practices and learning models } \\
\text { - Cross-border, inter-regional, and international co-operation }\end{array}$ \\
\hline
\end{tabular}

Source: OLEDA, 2008:3; OECD, 2009:11 
The CEO of OLEDA was expected to have the aforementioned competencies but focused only on fostering entrepreneurship development.

OLEDA was never in a position to undertake the capacity-building roles in-house. Capacitybuilding was facilitated through external experts.

The 0ECD report (OECD/Mountford, 2009:12) concluded that very few LED agencies are able to pursue this comprehensive list of competencies required. On completion of the establishment phase, it is time to take action.

\subsection{Phase three: Operationalise the agency}

In this phase it is important to appoint an accountant and to introduce a financial accounting system. All registrations must be done for example with the South African Revenue Services. The LED agency must also develop systems, policies and procedures that are similar to its parent municipality. In terms of chapter 6 of the Municipal Systems Act (Act 32 of 2000), the LED agency must develop a system to monitor and evaluate its performance. Internationally, LED agencies are set up for different reasons and with different objectives, depending on each municipality's unique circumstances (0ECD/Mounford, 2009:12, 13). The main objectives of an $L E D$ agency are important because this will be used in developing a performance management system. The performance management system is used to assess how well an LED agency is doing and to establish whether it contributed to the competitiveness of a town, city or region. The oECD (0ECD/Mountford, 2009: 22) found that it is desirable to have measures of progress (milestones) as well as ultimate goals in terms of the outputs and impacts of the interventions of the LED agency against which to measure performance. These milestones, outputs and impacts are measured in terms of the approved business plan on a quarterly or annual basis.

In the case of OLEDA, the budget was reviewed mid-term, and the milestones and performance indicators on a quarterly and annual basis in accordance to section 38 of the Municipal Systems Act (Act 32 of 2000). OLEDA's objectives were broken down into milestones and these were captured in the IDC business plans as milestones. The results were reported to the Overstrand municipality, the IDC and the OLEDA board of directors. In the event that a milestone was not reached, an explanation had to be given, accompanied by a plan of action indicating the corrective steps that will be taken. During the annual financial audit the auditor-general also conducted a performance audit on the milestones.

The OECD study established that that while LED agencies do have business-like structures, they nevertheless remain accountable to the municipality and are not entirely detached from it (0ECD/Mountford, 2009:15).

This was also the case with OLEDA. Although OLEDA was a private company owned by the Overstrand municipality and therefore a municipal entity in terms of the Municipal Systems Act (Act 32 of 2000), it had to account to its board of directors, the council of the municipality and to the IDC.

\subsection{Phase four: Consolidation and implementation}

The 0ECD report (OECD/Mountford, 2009:22) recommends that an LED agency have a clear process for reviewing the $L E D$ agency performance comprehensively every five years. This will enable some reflection on how far the mission has been achieved, and the work that still has to be done. The following issues can also be addressed: 
- Has the LED agency completed its task and should it be closed down?

- Does the LED agency need additional or new tools and resources to complete its task?

- Is it time for the LED agency to adjust and develop new or additional goals?

In the final section below the challenges and pitfalls of an LED agency are highlighted.

\section{CHALLENGES, BENEFITS AND PITFALLS OF AN LED AGENCY}

The $0 \varepsilon C D$ report (OECD/Mountford, 2009) found that LED agencies will experience challenges. Warning signals that might influence the $L E D$ agency negatively included the following: politicians feeling that the agency has become remote or distant from the municipality; serious concerns about how the LED agency is managing its resources; opposition to what the LED agency is doing; delayed projects or implementation; lack of a clear mandate from the date of establishment; staffing problems; financial problems; political and private sector interference; constant change; failure amongst citizens, political leaders and other stakeholders to understand why a more indirectly accountable corporate structure is preferred to a directly accountable municipal structure; a lack of strategic guidance on the part of LED agencies because a clear strategic framework was not set by responsible, elected leaders; and micromanagement by the municipality because of a lack of experience in how to deal with the LED agency at 'arm's length'. OLEDA experienced all of these challenges.

The LED agencies in the OECD study (0ECD/Mountford, 2009:5) reported that some of the benefits were that they were able to co-ordinate LED efforts better within their municipal area and were seen as the experts to do $L E D$. They were also able to increase the pace of delivering on $L E D$ projects and investor enquiries and had flexibility to respond to $L E D$ needs.

In the case of OLEDA the municipal legislative prescriptions and processes in respect of proposal calls and the disposal of municipal assets slowed the investor decision-making processes down. OLEDA first had to get board approval and then also council approval. The structure of OLEDA was also very rigid because of all the municipal compliance issues. Lastly, the plethora of municipal compliance issues created a barrier to effective service delivery. These challenges were, however, not insurmountable. The biggest stumbling blocks were that the mayoral committee and municipal manager were compliance-driven and not up to date with LED trends, and the parent municipality (Overstrand) still had an internal LED department. This created confusion in respect of the role of OLEDA and that of the internal unit. It is suggested that this kind of situation be avoided at all cost. To conclude, the key success factors for an LED agency are listed in TABLE 2.

\section{TABLE 2: Key success factors for LED agencies}

1. All political structures must show commitment.

2. The municipal manager must be competent

3. All stakeholders in the community and the private sector must participate.

4. The board of directors must be active and proactive; it should represent in a balanced way the different stakeholders; and it should display strong internal cohesion

5. One of the aims of the $L E D$ agency must be human upliftment. 
6. The LED agency should be the only mechanism used by the parent municipality to implement its LED strategies and plans.

7. The LED agency must provide focused services and projects.

8. The LED agency should have sufficient human and financial resources to implement its activities.

9. The LED agency must have a long-term financial plan that assures the self-sustainability, through diversified sources of income.

10. The LED agency must be supported by national role-players such as the IDC, SALGA, DBSA, LG SETA, the DTI and COGTA.

Source: Author's compilation

\section{CONCLUSION}

The main aim of this article was to provide guidelines on LED agencies to current and aspiring municipal $L E D$ practitioners. It was indicated that the importance of $L E D$ flows from the supremacy of the South African Constitution and that a municipality must do LED. LED practitioners in South Africa have two options available to do LED. This article only dealt with one, the external mechanism option, that of the LED agency. The comparison of OLEDA and the $0 \varepsilon C D / M o u n t f o r d ~ s t u d y$, which consists of research on 16 LED agencies, provides insight into the phases and issues that LED practitioners have to take into account when considering an LED agency as a vehicle for economic development. The main lessons learnt were that planning, communication and stakeholder involvement are necessary through all the phases. The reflection on lessons learnt within the developing South African LED context has provided insight into the challenges related to $L E D$ agencies. Taking cognisance of the case of OLEDA in comparison to the $0 E C D /$ Mountford research internationally could provide other LED practitioners in South Africa with guidelines in setting up and managing future LED agencies in the region. The article concludes with the key success factors derived from the lessons learnt from establishing OLEDA.

\section{LIST OF REFERENCES}

Black, P.A., Calitz, E., Steenkamp, T.J. and associates. (2005). Public Economics, $3^{\text {rd }}$ Edition, Oxford University Press, Cape Town.

Department of Cooperative Governance and Traditional Affairs (COGTA). (2012). Draft Local Economic Development Framework (2012-2017), Pretoria.

Davids, R. (2007). Current challenges of local economic development (LED): Origins and considerations for the future. A practice-based perspective. Prepared for the Foundation for Contemporary Research (FCR). Cape Town.

Department of Local Government. (DPLG). (2005). Policy Guidelines for Implementing Local Economic Development in South Africa. Pretoria. 
Department of Local Government (DPLG). (2006). Stimulating and developing sustainable local economies. Pretoria.

Fourie, M. \& Opperman, L. (2011). Municipal Finance and Accounting, $2^{\text {nd }}$ edition. Van Schaik, Pretoria.

International Labour Organisation (ILO). (2003). Overview and learned lessons on Local Economic Development, Human Development, and Decent Work. Geneva, pp. 1-51.

Nashira Davids, (Sunday Times 11 October 2012). Service-delivery protests getting uglier report [Online] Available: http://www.timeslive.co.za/thetimes/2012/10/11/service-deliveryprotests-getting-uglier---report. (Accessed 21 January 2013).

OECD/Mountford. D. (2009). Organising for local development: the role of local development agencies. Summary Report'. 26-27 November 2009, working document, CFE/LE\&D, 0ECD, pp. 140.

Overstrand Local Economic Development Agency. (OLEDA). (2008). Annual Report 2008/09, Overstrand.

Patterson, C. (2008). Country Report Local Economic Development in South Africa'Prepared for the GTZ strengthening local governance programme's LED component in South Africa.

Rabie, B. (2011). Improving the systematic evaluation of local economic development results in South African local government. Unpublished PhD thesis. Stellenbosch: Stellenbosch University.

Republic of South Africa (1996). Constitution of the Republic of South Africa Act no. 108 of 1996, Government Gazette, Pretoria.

Republic of South Africa (2003). Local Government. Municipal Finance Management Act no. 56 of 2003, Government Gazette, Pretoria.

Republic of South Africa (1998). Local Government: Municipal Structures Act no. 117 of 1998, Government Gazette, Pretoria.

Republic of South Africa (2003). Local Government: Municipal Structures Amendment Act No. I of 2003, Government Gazette, Pretoria.

Republic of South Africa (2000). Local Government: Municipal Systems Act no. 32 of 2000, Government Gazette, Pretoria.

Republic of South Africa (2003). Local Government: Municipal Systems Amendment Act No. 44 of 2003, Government Gazette, Pretoria.

Republic of South Africa (2011). Local Government: Municipal Systems Amendment Act No. 7 of 2011, Government Gazette, Pretoria.

Republic of South Africa (2005). National Treasury Regulations No. 308 and No. 309, Government Gazette, Pretoria.

South African Local Government Association (SALGA). (2011). A Councillor's Guide to Local Economic Development (LED) in South Africa; The Why? What? Who? and How? of LED. Prepared by SA LED Network for SALGA, Pretoria. 
South African Local Government Association (SALGA). (2010). Key issues in LED in South Africa and a potential role for SALGA. Prepared for the Department of Cooperative Governance and Traditional Affairs (COGTA). SALGA, Pretoria.

Swinburn, G., Goga, S., \& Murphy, F. (2006). Local Economic Development: a Primer developing and implementing local economic development strategies and action plans. The World Bank, Washington, D.C.

URBAN-ECON development economists. (2009). Shift Impact Assessment for the Establishment of a Development Agency. Prepared for the Capricorn District Municipality, Pretoria. 
Venter 